\title{
The Effect of Fatigue on Free Throw Kinematic Movement in Basketball
}

\author{
Agus Rusdiana*, Hamidie Ronald Daniel Ray, Angga \\ Muhammad Syahid \\ Faculty of Sport and Health Education \\ Universitas Pendidikan Indonesia \\ Bandung, Indonesia \\ *agus.rusdiana@upi.edu
}

\author{
Yuvi Setia Dwi Putra \\ Post Graduate of Sport Education Program \\ Universitas Pendidikan Indonesia \\ Bandung, Indonesia \\ yuvisetiadwiputra@studentupi.edu
}

\begin{abstract}
Free throw is a shoot that is done because it gets a foul on when entering the ball towards the ring with the value in one shoot is one. This study aims to determine the relationship and contribution of Centre of mass, angle of elbow joint, angular velocity of elbow joint, angle of wrist joint, angular velocity of wrist joint, release height of the ball, angle release of ball and angle release of upper arm against free throw throws that are affected by the fatigue condition. The method used in this study is a correlational descriptive, a sample of 10 player aged 16-18 years. Kinematic analysis used by kinovea software, Fastec high speed camera 32GB HDR-PJ540 camera, polar heart rate monitor watch and RAST test, data analysis using SPSS version 20 with correlation and regression analysis testing. The results of this study concluded from eight indicators only one that has a significant relationship and contribution to the result of free throw throw is angular velocity of wrist joint. The conclusion of this research is that it can be used as a reference for the science of coaching that how important to train movement basketball athlete in free throw at the condition of fatigue.
\end{abstract}

Keywords: basketball, fatigue index, kinematic, sport biomechanics

\section{INTRODUCTION}

Basketball is a very dynamic sport, where players have to shoot from some distance from the basket [1,2]. Basketball is one of the most popular sports in the world, fans of all ages feel that basketball is a fun sport, competitive, educational, entertaining and healthy. Personal skills such as shoot, bait, dribble, and rebound, as well as teamwork to attack or survive are the prerequisites for success in playing this sport. The game of basketball is a game that is played by hand, in the sense that the ball is always played from the hands of players in one team $[3,4]$. Lubay explained there are four basic techniques in basketball, ball handling, passing and catching, bouncing the ball to the floor (dribbling) and shooting [5]. The four techniques must be controlled by every basketball player together. Shooting movement is not just a mere throw of the ball, it also includes a directional gesture and tries to keep the ball falling on target, practicing in such a way that the ball falls right into the basket [6,7]. Therefore shooting must go in and on target to get points and win a game, such as the main goal in the game of basketball itself is to score and beat the opponent and win the game. Surely in a match, the player must try to make a shoot that creates a score or number for opponent team.

In basic shooting techniques, there is a wide range of shoots and various forms of shooting movement, one shoot in a basketball game is a free throw shoot, where the free throw itself. The shoot is done for getting a foul on entering the ball towards the ring with the value in one shoot is one $[8,9]$. Free throw is very important because the difference of one point in a basketball match will determine the team's winning.

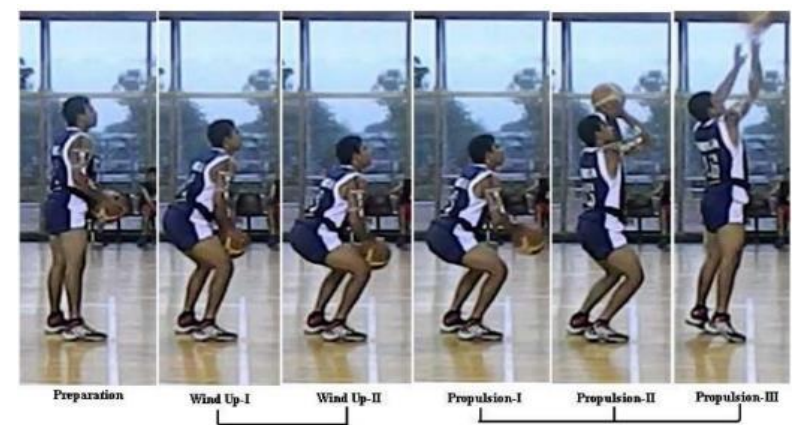

Fig. 1. Free throw motion series.

Today's technology is very sophisticated, with technology we can now get learning very quickly and easily, as well as by analysing a phenomenon both natural and human engineering. Biomechanics has been defined as the study of the movement of living things using the science of mechanics. Mechanics is a branch of physics related to the description of motion and how power creates motion [10]. Biomechanics can solve a problem in human movement as revealed by Knudson that Biomechanics is an important science to solve the problem of human movement [10]. Rusdiana argued that sports biomechanics provide an explanation of efficient and effective movement patterns of player, for example bio mechanists have used high-speed photography to study successful patterns of baseball pitcher movement [11]. Biomechanics is an interesting thing because it can explain how free throw movement performed well with the analysis in free throw movement, there are several indicators in determining the success of free throw that is Centre of mass, angle of elbow joint, angular velocity of elbow joint, angle of wrist joint, angular velocity of wrist joint, release height of the ball, angle release of ball and angle release 
of upper arm [12]. Some of these indicators affect the free throw because if one of them is not good it will lead to failure in the free throw itself, and certainly the team will not get free throw points.

One of the factors that affect free throw is fatigue, where Fatigue is an integral part of basketball game that can affect kinematics shooting an athlete $[13,14]$. In the previous study, show that fatigue has no effect on free throw kinematics shoot and no significant difference in joint angle between successful and unsuccessful shoots [13]. This study shows that high-level player (experts) are able to overcome the adverse effects of fatigue when performing coordinated movements such as free throw throws.

The research here focuses on how much correlation and contribution of kinematic movement indicator to free throw player throw results in fatigue or normal condition at player aged 15-17 years so that later can be used as a reference for the science of coaching.

\section{METHOD}

\section{A. Participants}

Subjects in this study are player basketball Garuda Bandung academy amounted to 10 players with aged range between 15-17 years.

\section{B. Research and Procedures}

In this study to take data used by Fastec high speed camera during free throw shoot implementation.

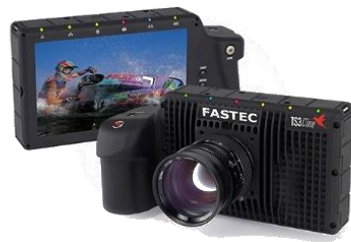

Fig. 2. Fastec high speed camera.

Used by recording in positions from the front of the player (bottom ring), recording which focuses on the player and record as a whole (athlete, ball and ring position).

To measure the number of calories released, acceleration, distance covered, heart rate used Polar heart rate monitor with attaching to the chest of player.

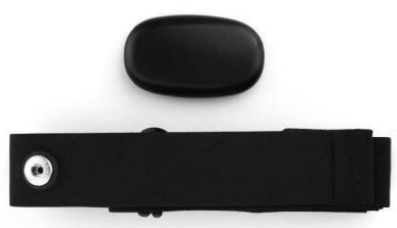

Fig. 3. Polar sensor heart rate monitor.

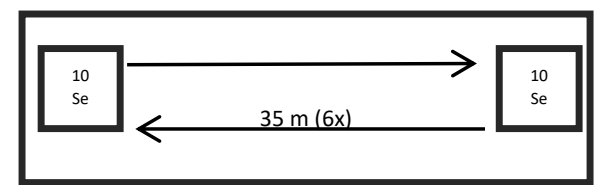

Fig. 4. RAST test scheme.

Fatigue index's testing is performed to see how much the index of fatigue in player, by measuring the maximum and minimum power released by the player and then divided the overall time of each repetition so as to get the results of fatigue index. Kinovea is a software that provides tracking system of the object path either automatically or manually. Kinovea can be used to analyse motion variations.

\section{The Free Throw Test}

The free throw test was conducted before and after the RAST test with each player performing 10 shoots in each test.

\section{RESULTS AND DISCUSSION}

Data on the calculation of test correlation and regression test of the study were analysed with the help of SPSS 20 . Here is a summary of the results:

TABLE I. CORRELATION TEST

\begin{tabular}{|c|c|c|c|c|c|}
\hline No & Indicator & Fatigue & $\mathbf{R}$ & Sig & Decision \\
\hline \multirow[t]{2}{*}{1} & \multirow[t]{2}{*}{$\begin{array}{l}\text { Centre of Mass } \\
\text { (Preparation) }\end{array}$} & $\begin{array}{l}\text { Before } \\
\text { fatigue }\end{array}$ & 0,018 & 0,961 & $\begin{array}{l}\text { Not } \\
\text { significant }\end{array}$ \\
\hline & & $\begin{array}{l}\text { After } \\
\text { fatigue }\end{array}$ & 0,177 & 0,625 & $\begin{array}{l}\text { Not } \\
\text { significant }\end{array}$ \\
\hline \multirow[t]{2}{*}{2} & \multirow[t]{2}{*}{$\begin{array}{l}\text { Centre of Mass } \\
\text { (Release) }\end{array}$} & $\begin{array}{l}\text { Before } \\
\text { fatigue }\end{array}$ & 0,149 & 0,681 & $\begin{array}{l}\text { Not } \\
\text { significant }\end{array}$ \\
\hline & & $\begin{array}{l}\text { After } \\
\text { fatigue }\end{array}$ & 0,224 & 0,534 & $\begin{array}{l}\text { Not } \\
\text { significant }\end{array}$ \\
\hline \multirow[t]{2}{*}{3} & \multirow[t]{2}{*}{$\begin{array}{l}\text { Angle of Elbow } \\
\text { Joint }\end{array}$} & $\begin{array}{l}\text { Before } \\
\text { fatigue }\end{array}$ & $-0,026$ & 0,943 & $\begin{array}{l}\text { Not } \\
\text { significant }\end{array}$ \\
\hline & & $\begin{array}{l}\text { After } \\
\text { fatigue }\end{array}$ & $-0,378$ & 0,282 & $\begin{array}{l}\text { Not } \\
\text { significant }\end{array}$ \\
\hline \multirow[t]{2}{*}{4} & \multirow[t]{2}{*}{$\begin{array}{l}\text { Velocity of } \\
\text { Elbow Joint }\end{array}$} & $\begin{array}{l}\text { Before } \\
\text { fatigue }\end{array}$ & 0,187 & 0,605 & $\begin{array}{l}\text { Not } \\
\text { significant }\end{array}$ \\
\hline & & $\begin{array}{l}\text { After } \\
\text { fatigue }\end{array}$ & $-0,205$ & 0,569 & $\begin{array}{l}\text { Not } \\
\text { significant }\end{array}$ \\
\hline \multirow[t]{2}{*}{5} & \multirow[t]{2}{*}{$\begin{array}{l}\text { Angle of Wrist } \\
\text { Joint }\end{array}$} & $\begin{array}{l}\text { Before } \\
\text { fatigue }\end{array}$ & 0,428 & 0,217 & $\begin{array}{l}\text { Not } \\
\text { significant }\end{array}$ \\
\hline & & $\begin{array}{l}\text { After } \\
\text { fatigue }\end{array}$ & 0,260 & 0,469 & $\begin{array}{l}\text { Not } \\
\text { significant }\end{array}$ \\
\hline \multirow[t]{2}{*}{6} & \multirow[t]{2}{*}{$\begin{array}{l}\text { Velocity of } \\
\text { Wrist Joint }\end{array}$} & $\begin{array}{l}\text { Before } \\
\text { fatigue }\end{array}$ & 0,639 & $0,047 \mathrm{a}$ & Significant \\
\hline & & $\begin{array}{l}\text { After } \\
\text { fatigue }\end{array}$ & 0,672 & $0,033 a$ & Significant \\
\hline \multirow[t]{2}{*}{7} & \multirow[t]{2}{*}{$\begin{array}{ll}\text { Height } & \text { Ball } \\
\text { Release } & \end{array}$} & $\begin{array}{l}\text { Before } \\
\text { fatigue }\end{array}$ & $-0,258$ & 0,472 & $\begin{array}{l}\text { Not } \\
\text { significant }\end{array}$ \\
\hline & & $\begin{array}{l}\text { After } \\
\text { fatigue }\end{array}$ & $-0,124$ & 0,733 & $\begin{array}{l}\text { Not } \\
\text { significant }\end{array}$ \\
\hline \multirow[t]{2}{*}{8} & \multirow[t]{2}{*}{$\begin{array}{l}\text { Angle Release } \\
\text { of Ball }\end{array}$} & $\begin{array}{l}\text { Before } \\
\text { fatigue }\end{array}$ & $-0,302$ & 0,396 & $\begin{array}{l}\text { Not } \\
\text { significant }\end{array}$ \\
\hline & & $\begin{array}{l}\text { After } \\
\text { fatigue }\end{array}$ & $-0,384$ & 0,274 & $\begin{array}{l}\text { Not } \\
\text { significant }\end{array}$ \\
\hline \multirow[t]{2}{*}{9} & \multirow[t]{2}{*}{$\begin{array}{l}\text { Angle Release } \\
\text { of Upper Arm }\end{array}$} & $\begin{array}{l}\text { Before } \\
\text { fatigue }\end{array}$ & $-0,234$ & 0,516 & $\begin{array}{l}\text { Not } \\
\text { significant }\end{array}$ \\
\hline & & $\begin{array}{l}\text { After } \\
\text { fatigue }\end{array}$ & $-0,195$ & 0,589 & $\begin{array}{l}\text { Not } \\
\text { significant }\end{array}$ \\
\hline
\end{tabular}


between the accuracy of free throws and shoulder angle displacement during the forward swing [15].

The table above shows that many indicators are insignificant due to sig value $>0.05$, but there is one indicator that has significant relation that is velocity of wrist joint with significant value. $<0.05$.

After the correlation test, performs regression test to see the percentage of correlation level of velocity of wrist joint, following the regression test of velocity of wrist joint:

\section{TABLE II. REGRESSION TEST}

\begin{tabular}{|l|l|l|l|l|}
\hline No & \multicolumn{1}{|c|}{ Variable } & \multicolumn{1}{|c|}{$\begin{array}{c}\text { R } \\
\text { Square }\end{array}$} & sig. & Decision \\
\hline 1 & $\begin{array}{l}\text { Velocity of wrist joint } \\
\text { before fatigue }\end{array}$ &, 409 &, $047 \mathrm{a}$ & Significant \\
\hline 2 & $\begin{array}{l}\text { Velocity of wrist joint } \\
\text { after fatigue }\end{array}$ &, 452 &, $033 \mathrm{a}$ & Significant \\
\hline
\end{tabular}

The above table shows $\mathrm{R}$ square of velocity of wrist joint before fatigue of 0.409 and sig. $0.047 \mathrm{a}$ while $\mathrm{R}$ square of velocity of wrist joint after fatigue of 0.452 and sig. $0.033 \mathrm{a}$, it showed that the percentage of velocity of wrist joint before fatigue is $41 \%$ and after fatigue $45 \%$ to free throw results because if the number of $\mathrm{R}$ square is worth 1 then it can be said $100 \%$ percentage.

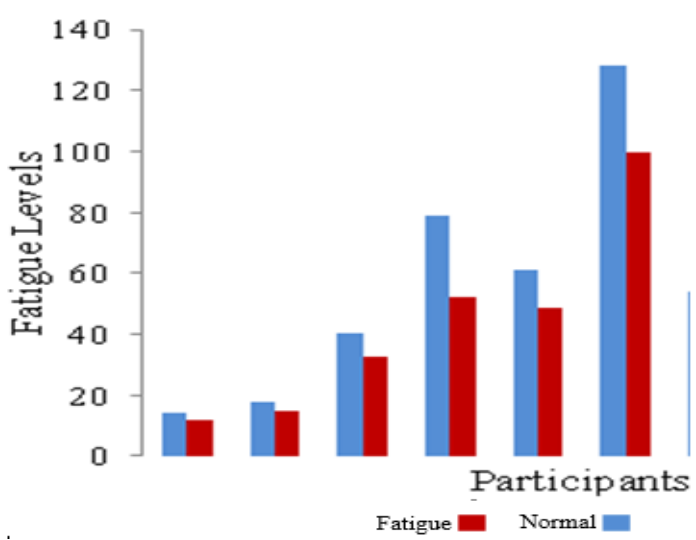

Fig. 5. Average data of the indicators.

The above data shows the decrease of angle and velocity before fatigue and after fatigue, there is positive and negative correlation of each indicator by looking at value from correlation test, for positive value hence can be said that if there is increase of angle or velocity hence result of throw increase or can if there is a decrease in angle or velocity then the result of the throw decreases.

The average correlation before fatigue or after fatigue results shows the same correlation that is positive before fatigue and positive after fatigue, but angle o elbow joint and angular velocity of elbow joint where befor fatigue positive correlation, it caused by player who are too ra $\mathrm{I}$ in doing a free throw because of the defeat so that player do not concentrate. This causes the angular velocity of the shoulder to change so that it affects the accuracy of the shot as has been suggested in previous studies that there is a significant positive correlation

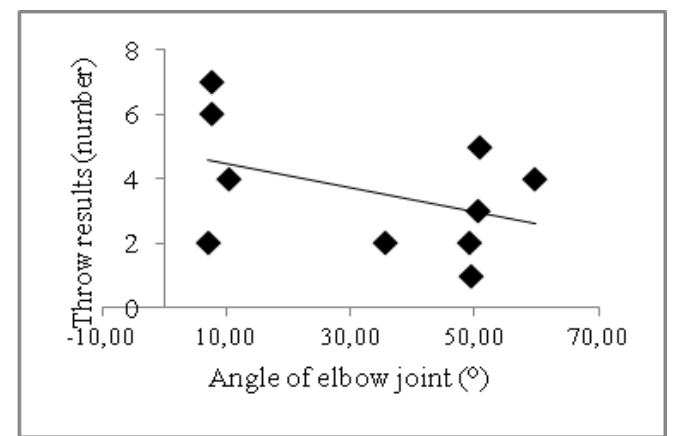

Fig. 6. Correlation angle of elbow joint after fatigue.

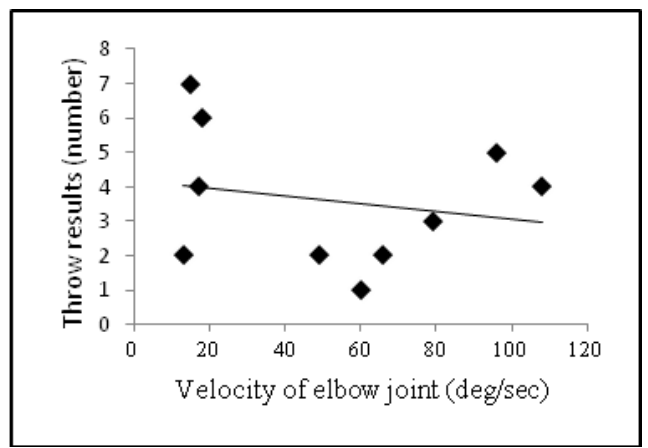

Fig. 7. Correlation of angular velocity of elbow joint after fatigue.

The line from the graph above shows that there is a negative correlation where when the angle or velocity rises the result of the throw decreases or can be said when the angle or velocity decreases then the result of the throw increases.

For release height of ball, angle release of ball and angle release of upper arm shows negative correlation value before fatigue, because the three indicators are related. These results support previous research which explains there is no effect caused by significant fatigue in free-throw shots. However, we must also remember that the effects of fatigue on non-elite or young players, whose strength will be more important in shooting free throws than the coordination component, may be more influential during free throws [13].

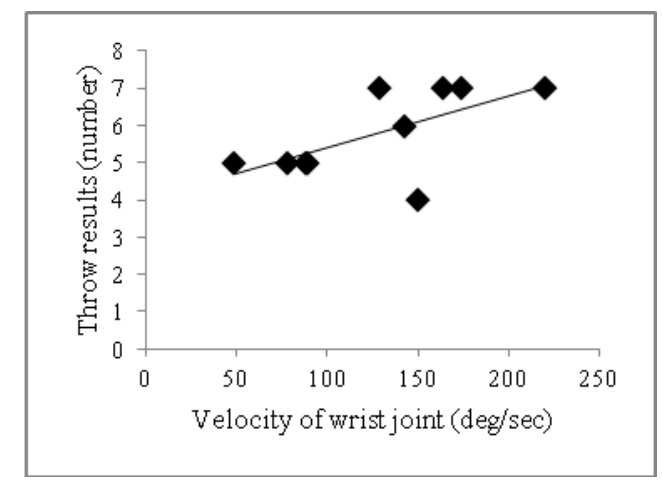

Fig. 8. Correlation of angular velocity of joint before fatigue. 


\section{REFERENCES}

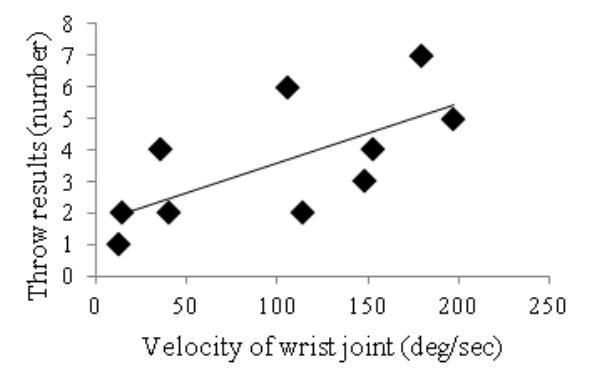

Fig. 9. Correlation of angular velocity of joint before fatigue.

The above graph indicates that the angular velocity of joint is positively correlated to the throw result when at the moment the angular velocity of joint rises, the result of the throw increases, the result of the throw decreases. These results support previous research which explains the existence of an important relationship between hand speed and body angle that there is an endless combination of segment contributions in relation to various projected angles and speeds that can produce successful shots [16].

\section{CONCLUSIONS}

From all the above discussion it can be seen that the athlete is able to maintain every indicator in doing free throw shoots, although with the condition of player who are in fatigue condition, but there is one significant relationship that is on velocity of wrist joint. It can be concluded that the greatest contribution in the influence of fatigue on kinematic movement free throw, in line with research conducted by Okazaki which suggests that bigger contribution comes from wrist hand and have been observed on shooting expert players [12]. This Result submitted the recommendation in the hope that it would be beneficial to all interested parties.
[1] V.H.A. Okazaki and A.L.F. Rodacki, "Increased distance of shooting on basketball jump shot," J. Sport. Sci. Med., vol. 11(2), pp. 231-237, 2012.

[2] R.R. Oudejans, J.M. Koedijker, I. Bleijendaal and F.C. Bakker, "The education of attention in aiming at a far target: Training visual control in basketball jump shooting," International Journal of Sport and Exercise Psychology, vol. 3(2), pp. 197-221, 2005.

[3] Sucipto, Permainan Bola Basket. Bandung: FPOK UPI, 2010.

[4] J. Bourbousson, C. Sève and T. McGarry, "Space-time coordination dynamics in basketball: Part 2. The interaction between the two teams," Journal of Sports Sciences, vol. 28(3), pp. 349-358, 2010.

[5] D. Budiana and L.H. Lubay, Pembelajaran Permainan Bola Basket. Bandung: PJKR FPOK UPI, 2013.

[6] V. Amber, Petunjuk Untuk Pelatih Dan Pemain Bola Basket. Bandung: CV Pionir Jaya, 2013

[7] R.R. Oudejans, R.W. Van De Langenberg and R.V. Hutter, "Aiming at a far target under different viewing conditions: Visual control in basketball jump shooting," Human movement science, vol. 21(4), pp. 457-480, 2002.

[8] D. Kosasih, Fundamental Basketball First Step to Win. Semarang: CV. Elwas Offset, 2008.

[9] A.S. Smith, "Shooter's Touch: Skill Mastery in Basketball through SkillAppropriate Progressions," Strategies, vol. 30(4), pp. 11-16, 2017.

[10] D. Knudson, "Biomechanics of the Basketball Jump Shot-Six Key Teaching Points," J. Phys. Educ. Recreat. Danc., vol. 64(2), pp. 67-73, 1993.

[11] A. Rusdiana, H. A. Junanda and N. I. Rahayu, "Kecepatan dan Akurasi Shuttlecock pada Jump Smash dengan Loncatan Vertikal dan Parabol Depan dalam Bulutangkis," J. Terap. Ilmu Keolahragaan, vol. 1(1), pp. 17, 2016.

[12] V.H.A. Okazaki, A.L.F. Rodacki and M.N. Satern, "A review on the basketball jump shot," Sport. Biomech., vol. 14(2), pp. 190-205, 2015.

[13] M. Uygur, A. Goktepe, E. Ak, H. Karabörk and F. Korkusuz, "The effect of fatigue on the kinematics of free throw shooting in basketball," J. Hum. Kinet., vol. 24(1), pp. 51-56, 2010.

[14] T. Rupčić, D. Knjaz, M. Baković, A. Devrnja and B. Matković, "Impact of fatigue on accuracy and changes in certain kinematic parameters during shooting in basketball," Hrvatski športskomedicinski vjesnik, vol. 1(30), pp. 15, 2015.

[15] M. Ogawa, S. Hoshino, M. Fujiwara and H. Nakata, "Relationship between basketball free-throw accuracy and other performance variables among collegiate female players," J. Phys. Fit. Sport. Med., vol. 8(3), pp. 127-136, 2019.

[16] A. Ammar, H. Chtourou, O. Abdelkarim, A. Parish, and A. Hoekelmann, "Free throw shot in basketball: kinematic analysis of scored and missed shots during the learning process," Sport Sci. Health, 2015 . 